\title{
A Pan-African space in Cape Town? The Chimurenga archive of Pan-African festivals
}

\section{Alice Aterianus-Owanga}

To cite this article: Alice Aterianus-Owanga (2019): A Pan-African space in Cape Town? The Chimurenga archive of Pan-African festivals, Journal of African Cultural Studies, DOI: 10.1080/13696815.2019.1632696

To link to this article: https://doi.org/10.1080/13696815.2019.1632696

曲 Published online: 23 Aug 2019.

Submit your article to this journal $₫$

Q View related articles $₫$

View Crossmark data \lceil 


\title{
A Pan-African space in Cape Town? The Chimurenga archive of Pan-African festivals
}

\author{
Alice Aterianus-Owanga \\ Institut de sciences sociales des religions, Université de Lausanne, Lausanne, Switzerland
}

\begin{abstract}
Created in 2002 in Cape Town by Ntone Edjabe, Chimurenga is a multidimensional project that combines a print magazine, a workspace, a platform for editorial and curatorial activities, an online library, and a radio station (the Pan-African Space Station). Based on collaborative ethnographic research with the Chimurenga team, this paper discusses the collection, production and creation of an archive about Pan-African festivals that this collective has developed through their cultural activities. After a brief overview of Festival of Black Arts and Culture (FESTAC) which took place in Lagos in 1977, and the history of Pan-African festivals, I describe the materials collected by Chimurenga and the projects in which they have participated. By following the travelling routes which have led to this informal and unstable collection of materials, I highlight how Chimurenga's work contributes to challenging the idea of the archive, transformed through their practice into a dynamic and generative medium. I consider how the archive and memory of FESTAC is spread by Chimurenga in global and local spheres, and how it is used to produce new cultural and art forms in the present day, scrambling boundaries between past, present and future to perform a PanAfrican transtemporal space in South Africa.
\end{abstract}

\section{KEYWORDS}

Pan-Africanism; archives; festivals; FESTAC; memory; Cape Town; South Africa; Chimurenga

The real failure regarding FESTAC ' 77 is not its turbulent history but rather our failure to acknowledge the meaning of that history and its relationship to the contemporary.

The question we ask is: can a past that the present has not yet caught up with be summoned to haunt the present as an alternative? What is important here is not the reiteration of the actual past, but the persistence of what never actually happened, but might have. ${ }^{1}$

The Chimurenga project explained in these words above their interest in the Festival of Black Arts and Culture (often called FESTAC) that took place in Lagos in 1977, and how they used this part of African history to address current issues regarding culture and politics in contemporary Africa. Since 2010, this South Africa-based team of writers and journalists has collected and produced a large series of archival materials about FESTAC and the broader history of Pan-African festivals. ${ }^{2}$ Their intention is to create alternative memory practices and knowledge, that they perform through various platforms and medias, in South Africa and in the world. Navigating between afro-futurism and Pan-Africanism, 
Chimurenga considers FESTAC as a haunting past that can provide powerful tools to reflect on the present and the future of Africa and the African diaspora.

FESTAC was the biggest Pan-African festival organised on the African continent in the twentieth century. Launched by the Nigerian military state in an attempt to rebuild the country after the civil war, the festival was thought of as a huge meeting point of the Black world, from both the diaspora and the continent. It was following a broader history of Pan-African festivals organised on the continent since the beginning of the independence era (Apter 2005; Murphy 2016b) and it is often considered as the ending point of this great era of the Pan-African ideal. Even if many cultural events and festivals have subsequently continued this Pan-African attempt, no other Pan-African literary or music event succeeded in reaching the scale of FESTAC in terms of participants, guests, and length.

Chimurenga, created in 2002 in Cape Town by Ntone Edjabe, is a multidimensional project that combines a print magazine ('The Chronic', a 'Pan-African publication of culture, art and politics'), a workspace, a platform for editorial and curatorial activities, an online library, and a radio station (the Pan-African Space Station). Writers and journalists who form the Chimurenga team are often part of literary festivals in South Africa or abroad, and they organise concerts and performances - in their Cape Town office or in local cultural centres such as Guga Tshebe in the Langa township, to which they invite poets, writers, musicians and DJs of different genres and generations, who support a same project of 'exploring new territories' (Chimurenga website). An exploration of the websites created for their radio, the Pan-African Space Station, ${ }^{3}$ and for their magazine, ${ }^{4}$ provides an insightful overview of the afrofuturist aesthetic and the multiple activities developed by Chimurenga around their Pan-African attempt. In addition to their publications and local activities in South Africa, Ntone Edjabe and his team have travelled around the world since the end of the 2000 s to propose exhibitions and pop-up events in libraries, museums and cultural institutions, where they draw on the archives that they produce and collect in order to create a 'time-travel machine' to the past. Using FESTAC history, and more broadly Pan-African history, their explicit intention is to generate alternative knowledge about Africa, the diaspora and more broadly, revolutionary liberation movements, connecting different periods and spaces through sound, music, words, narratives, comics and maps (Figure 1).

Like other artistic and cultural projects (Baumann 2009; Le Lay, Malaquais, and Siegert 2015; De Jong and Harney 2015), the Chimurenga project offers an interesting example of the contemporary phenomenon of archival production handled by artists or cultural actors. Indeed, in their attempt to document the history of Pan-African festivals, Chimurenga has both collected existing (official or unofficial) documents and created new materials, using historical materials to create new art forms, memories and political commentaries on the present state of Africa and South Africa. Through this attempt, Chimurenga contributes to the global, heterogeneous, and interconnected series of movements which participate in the reinvention of the Pan-African ideal and utopia in the present day.

Pan-Africanism can be defined as a movement and ideology which considers that people in Africa and in the diaspora share, in some way, a common history, struggle and destiny. Since the eighteenth century, a variety of organisations, intellectuals, artists and activists located on all sides of the Atlantic have 'looked forward to a genuinely united and independent Africa as the basis for the liberation of all Africans, both those on the continent and in the diaspora' (Adi 2018, 3). Pan-African movements and ideas 


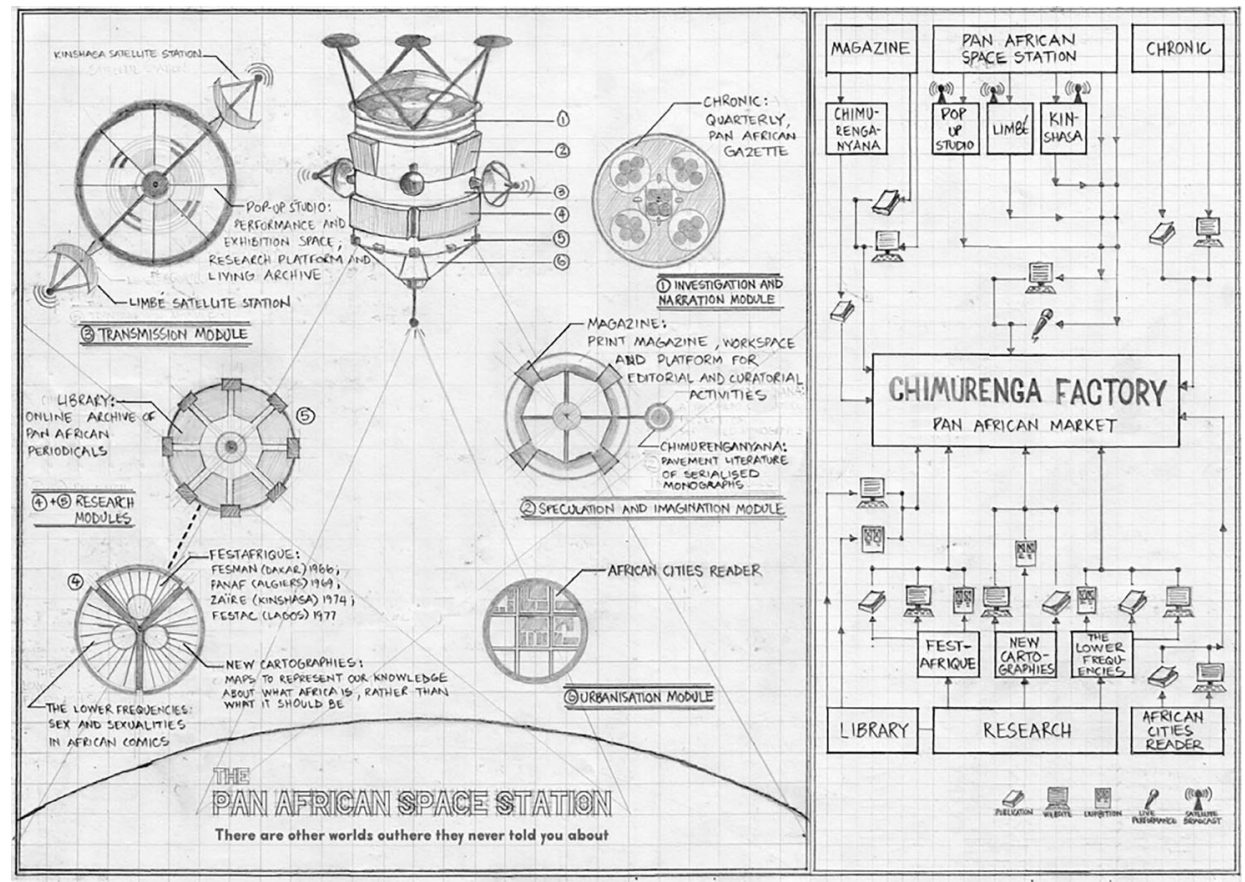

Figure 1. Schema of Chimurenga's organisation (copyright ๑ Chimurenga).

have accompanied liberation and independence struggles, and infused into all strata of society, including religious and artistic domains (Bonacci 2010; Guedj 2012). For this reason, George Shepperson has distinguished between 'Pan-Africanism' (with a capital letter), a clearly recognisable ideological movement, and 'pan-Africanism (with no capital letter): a group of movements (often ephemeral) 'where the cultural element dominates' while at the same time being clearly inspired by Pan-African ideologies (Shepperson 1962, 347), in the manner of Chimurenga.

My interest in this paper is to understand the different kinds of 'archives' that Chimurenga creates through their travels, encounters and performances, and to highlight how the production and performance of the archive is the relay for a discussion about the Pan-African ideal in South Africa. ${ }^{5}$ This research expands upon studies that pay attention to past and contemporary forms of Pan-Africanisms (Shepperson 1962; Boukari-Yabara 2014; Adi 2018), and to relationships with archives and memory in South Africa (Hamilton et al. 2002; Harris 2002; Saunders 2010; Mangcu 2011), especially in the arts. ${ }^{6}$

This article is based on a six months collaborative ethnography of Chimurenga's activities, during which I worked in their Cape Town office and explored the materials they have collected about FESTAC, in order to participate in the indexation and organisation of this archive. Using participant observation, several interviews and informal discussions with Chimurenga members, and descriptions of their materials, my article offers insight into the history and memory of FESTAC that they are re-writing, and it traces the pathways that have driven this archival impulse. After a brief overview of FESTAC and the history of Pan-African festivals, it describes the materials collected by Chimurenga and the projects that they have participated in. By following the travelling routes which 
have led to this informal and unstable collection of materials, I highlight how Chimurenga's work contributes to challenge the idea of the archive, transformed through their practice into a 'dynamic and generative medium' (Osthoff 2009). I finally consider how FESTAC archive and memory is spread by Chimurenga in global and local spheres, and how it is used to produce new cultural and art forms in the present day, scrambling boundaries between past, present and future to perform a Pan-African transtemporal space in South Africa.

\section{FESTAC, Pan-African festivals, and the archival impulse}

From 15 January 1977-12 February 1977, Lagos hosted the biggest Pan-African festival to take place on the African continent following independence, the Festival of Black Arts and Culture. During the 29 days 'that shook the Black world', ${ }^{7}$ more than 17.000 people from 52 countries were gathered for a gigantic event. The festival included a major colloquium attended by 700 delegates, a large programme of concerts with renowned artists from both sides of the Atlantic - Miriam Makeba, Stevie Wonder, Sun Ra, The Blue Notes, Gilberto Gil, Franco Luambo Makiadi - a regatta, and durbars.

FESTAC built upon other Pan-African festivals that had been organised previously, each with distinct ideological backgrounds. FESMAN was organised in Dakar in 1966 under the co-patronage of Leopold Sedar Senghor and General de Gaulle, to assert Negritude and Black African culture, with an elitist conception of arts and culture (Ficquet and Gallimardet 2009; Murphy 2016b). Even if all African nations were invited to participate, several artists and countries -such as Guinea - boycotted the event, considered as a neo-colonial venture (Murphy 2016b, 23). Another Pan-African festival took place in Algiers in 1969, after the 1965 revolution of Houari Boumediene. Contrary to FESMAN, the Pan-African Cultural Festival of Algiers (PANAF) was a response towards the nationalist revolutionary politics of the era, gathering liberation movements such as FRELIMO, ZAPU, ANC, MPLA, and the Black Panthers (Gallimardet 2010). The festival directly challenged Senghor's ideology of Negritude and Black identity, to rather assert a continental cultural identity.

Eight years later, FESTAC intended to go beyond these two antagonistic visions of culture and Pan-Africanism - the first one centred around Negritude and Senghor's intention to perform an African Renaissance (Murphy 2016a, 131), the second focusing on the idea of art as a revolutionary medium. Beyond this division between Senghor and Boumediene, FESTAC was inviting all African nations, liberation movements and diasporic communities to send their delegations. ${ }^{8}$ It had no explicit ideological agenda like FESMAN (with Negritude) or PANAF (with revolution), but its organisation was clearly infused by the military state's will to impose Nigeria as the capital of a Pan-African new world, and as a huge performance of nationalism (Apter 2005). As the last big Pan-African festival of the twentieth century, FESTAC marked a point of entry into an era of structural adjustment, economic crisis, and disenchantment following the liberation struggles that had transformed the African continent and the diaspora for several decades.

Recently, Pan-African festivals have become the object of a new archival impulse, with a visible will to rehabilitate this cultural phenomenon, whether it be from artists, scholars or African states themselves, for example with the organisation of a second Panaf' in Algiers in 2009, or with a second FESMAN organised by Abdoulaye Wade in Dakar in 2010. David Murphy has recently discussed how the archive and memory of FESMAN 1966 were 
evoked and used by Senegalese President Abdoulaye Wade in FESMAN 2010, in order to serve new purposes:

Wade turned to the past as an archive from which to imagine a utopian future, although it was a future that a great number of his many opponents would have deemed dystopian ... While the 1966 festival was built on the ideological foundations provided by Senghor's Negritude, FESMAN 2010 had much more diverse ideological moorings that veered between a diffuse sense of a shared Pan-African culture and a far more racialized form of Afrocentric thought. (Murphy 2016a, 132)

New Pan-African festivals were organised in order to celebrate the era of utopianism, PanAfricanism and liberation that twentieth century festivals represented (Murphy 2016a, 2016b). They were still endowed with an intention to define a global Black consciousness by performance. However, the use of archives and references to previous festivals were taking new meanings with new purposes, as highlighted by the example of Wade's assertion of an Afrocentric vision of blackness.

What about the archive of FESTAC and its commemoration? Despite the incredible scale of FESTAC 77, and the importance that this moment has played for various countries and liberation movements, its history has long remained unknown, both in Nigeria and abroad. In Nigeria, the name FESTAC is known as an area of Lagos that was built in 1977 to welcome the different delegations of the festival, but few people remember the event to which it is related (Ekpo 2008). Far away from the former 'FESTAC village', an institution has been built in the centre of Lagos, to collect the archive material related to the event (CBAAC: Center for Black Arts and Culture). However, this place is not frequented by the ordinary citizens, and it has not become a popular 'lieu de mémoire' (Nora 1984) among the population. In 2007 and 2017, local celebrations were organised by CBAAC, but as asserted by Denis Ekpo (2008), the legacy of the event, its memory and its archives have been primarily appropriated and recuperated by the Nigerian State as a legacy for celebration of cultural nationalism, leaving behind the global Pan-African ideal and connections that supported the event.

Even if FESTAC's Pan-African utopia and memory have partly been erased in the Nigerian context, a series of attempts have been made by Panafest (Malaquais and Cedric 2016), bringing together scholars and artists from several continents around the Atlantic Ocean, in order to create a memory of this event. ${ }^{9}$ The group, headed by Dominique Malaquais, Cedric Vincent and Eloi Ficquet, has to that purpose collected several interviews with people who have participated in Pan-African festivals, and a series of archive documents that have constituted the basis of several recent papers and exhibitions, that mention FESTAC. In the artistic domain, the photographer Marilyn Nance has also exhibited her pictures of FESTAC in a few events, including Chimurenga's exhibition in New York or Panafest exhibition at Museum of Quai Branly in Paris (Nance and Robles 2017). As the official photographer of the North-American Delegation, she collected a photographic record of the black African Americans who were part of FESTAC in 1977.

In connection with these scholars and artists, the Chimurenga team started in 2010 to collect, produce and exhibit a large series of archival materials in order to generate memory and knowledge about FESTAC, within the broader history of Pan-African festivals. Contradicting political nation states' recuperations of Pan-African legacy, they use materials from the past to invent popular performances manifesting Pan-Africanism, 
and to spread new Pan-African utopias (Murphy 2016a). While scholars such as Toyin Falola and Kwame Essien (2013) argue that the idea of Pan-Africanism has been eclipsed by the concept of diaspora, thus less related to race and racism, members and collaborators of Chimurenga contribute to reinvent a global Pan-Africanism, and to use it as a tool of liberation and contestation of Western conceptions of knowledge (see also Bosch Santana 2016). As I will describe in the following section of my discussion, the memory and performances they create around FESTAC overlap with Chimurenga's local history in Cape Town, and with the transnational routes of its founding member Ntone Edjabe.

\section{Ntone Edjabe's Chimurenga: Pan-African routes and local roots}

While deeply transnational and mobile, Chimurenga was for a long time almost inseparable from the institution and location where it was born: the Pan-African market. Based at 76 Long Street in Cape Town, the Pan-African market is a three-storey building that assembles several dozen traders and artists from different African countries, and represents a popular area for Cape Town's tourists and lovers of African crafts. The two rooms that composed Chimurenga's offices were located on its third floor, next to a permanent exhibition by African painters, mainly originating from Democratic Republic of Congo. The first room was the editorial office, where the designer and the subeditors worked, while the second office was composed of several desks, sofas, and an exhibition of Chimurenga products on sale: their gazette, magazines, books and T-Shirts (Figures 2 and 3).

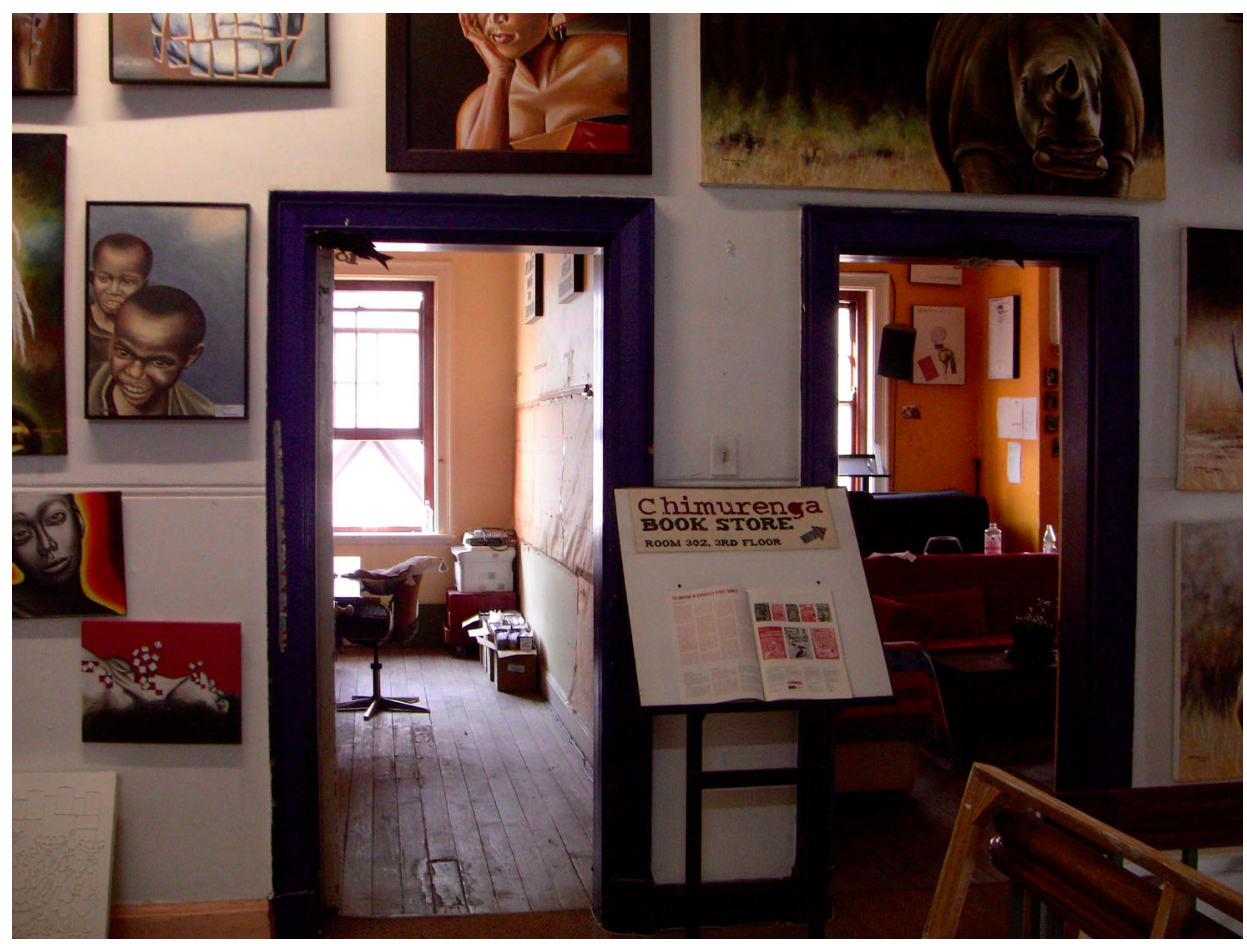

Figure 2. Chimurenga's office in the Pan-African market (photo by the author). 


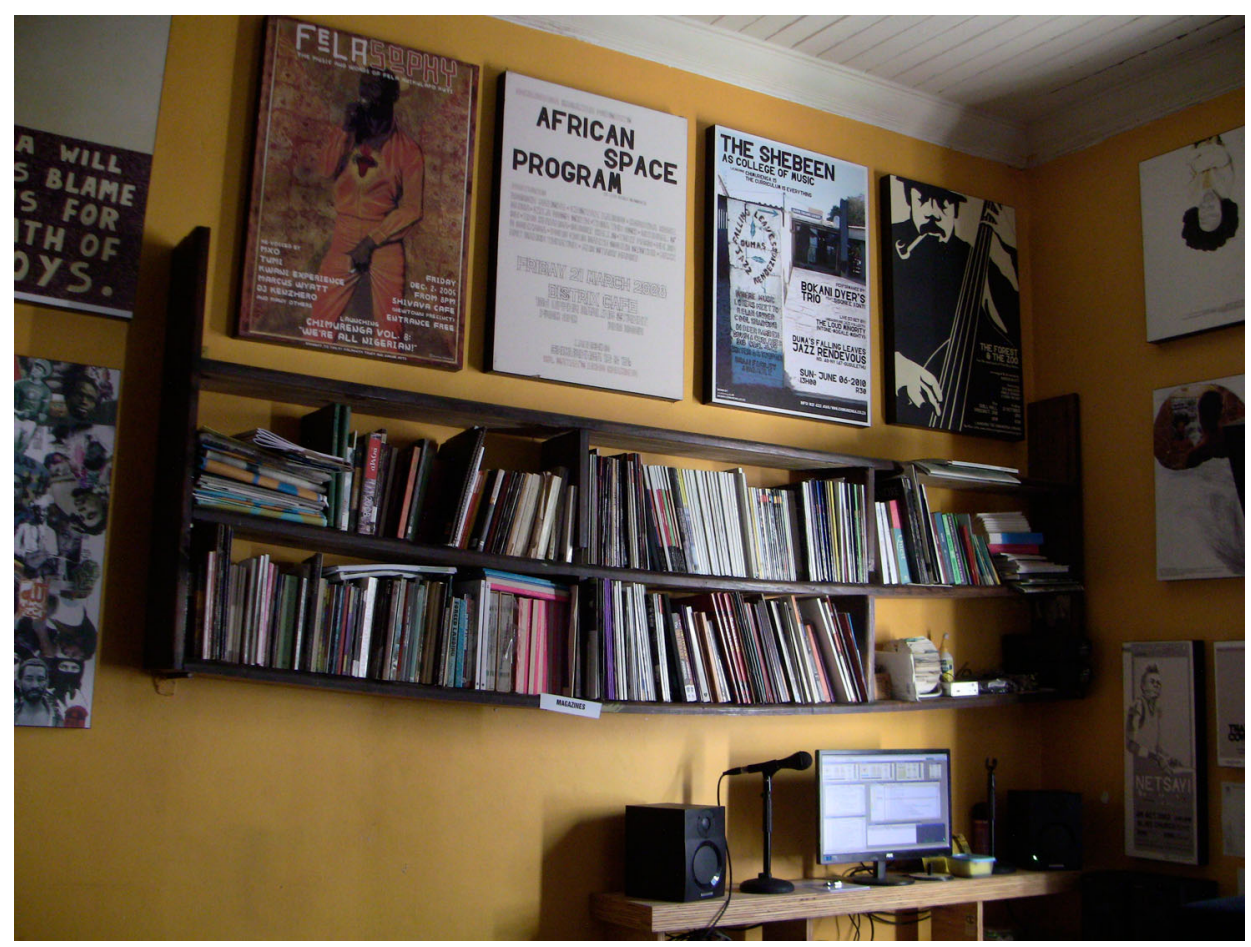

Figure 3. Chimurenga's office in the Pan-African market (photo by the author).

The Pan-African market was created in 1996 by Vuyo Koyana and Ntone Edjabe, in order to offer a meeting place for African migrants and South-African people who didn't feel integrated in Cape Town, a town largely considered to exclude black people and particularly non-South African Africans:

We had an experience of alienation in the city, so we had to create a space where we could gather, where there was not necessarily this sensation of being alone (Interview with Ntone Edjabe, August 2015, my translation from French).

The Pan-African Market became a home for some 'foreign' (that is non-South African) Africans, and for South African people who experienced a feeling of exclusion in the city or who chose a Pan-African identification rather than a national one. Cape Town, in the meantime, was entering a process of sanitisation of its public spaces (including the domain of the informal market), related to the City Improvement Districts' policies and entrepreneurial governance. ${ }^{10}$ This creation of 'selected, sanitised and disciplined zones as a highly 'aestheticised commodity' for global investment and consumption' (Miraftab 2007, quoting Mbembe 2004, 394) led to an exclusion of informal traders and the poorest classes from the CBD (Central Business District), for the benefit of investors and neoliberal agendas. For Chimurenga, their city-centre location, within the Pan-African market, was considered as an act of resistance against the exclusionary spatial politics towards marginalised populations, seeking to create a Black and African space in Cape Town. However, recently, these systems of exclusion of African elements in the central town area have taken on a stronger meaning, as Chimurenga has been forced to move, 
because their building was supposed to be shifted to investors. The Pan-African market and Long Street small traders had not yet been displaced at the moment of the finalisation of this article, but Chimurenga is now located in Woodstock, an old district of Cape Town famous for its 'gentrification' and its artistic liveliness.

The history of Chimurenga and the 'Pan-African' market were related mainly because of Ntone Edjabe, a central character in the history of both institutions. His pathway is important in order to better understand the history of Chimurenga, its travelling routes, and its visions of Africa and Pan-Africanism. ${ }^{11}$ Ntone Edjabe was born in Douala, Cameroon, where he spent most of his youth, and from where he draws his first memories and his passion for music, sport, and writing. He left Cameroon for Nigeria to pursue his university studies, before finally leaving Nigeria for South Africa in 1993, in order to access what he considered to be the best level of academic training in Africa. When he arrived, his ID documents and money were stolen, and he had to find ways to survive in a very particular moment in South Africa's history:

I find myself at the YMCA, a Christian youth center in Braamfontein, in the basement of a building. I'm given a space in the basement, where I do the dishes, and where there was practically an ANC army who took refuge and waited for the call. Actually, the guy who could have become South Africa's first real president, Chris Hani, had been murdered. I found myself parachuted in this place without knowing what was happening. (Interview with Ntone Edjabe, August 2016, my translation from French)

Immediately on his arrival, Ntone was immersed in the inside of the liberation struggles occurring at that time in South Africa, and he became friends with many people involved in the ANC. This experience represents for him a brutal and transforming encounter with riots for liberation that occurred in South Africa at that time:

I experienced a very brutal discovery of what was happening here, like a 'boom'. And it was the first time ... Because it's true that in Cameroon, I had seen the riots for a multi-party system, that were rather brutal, and in Lagos, I had seen student riots. But this kind of determination, this national struggle that had lasted for decades, long before I was born ... It was the first time that I was in a space like that. (Interview with Ntone Edjabe, August 2016, my translation from French)

The first points of entry in South Africa for Ntone, the encounter with 1993's struggles against apartheid, constituted a main lever for the raising of his Pan-African consciousness. A few months later, following his friend Sandile Dikeni - a South African poet and journalist who was strongly involved in the political struggle for freedom in South Africa - he left Johannesburg for Cape Town, where he settled and started to write his first texts for the local newspaper, in the midst of other multidimensional activities. Passionate about music since his childhood, Ntone Edjabe also started a radio programme, and became connected to the music and art scene in Cape Town. At the same time, as basket-ball coach, he created a basket-ball journal named Oups Africa, that he describes as his first 'PanAfrican' experiment of publishing, because it gathered authors from different African countries. His interest in the intersections between culture, body performances and politics grew at this period.

At the same time, his experience as an exile and a foreigner, in a city which was still deeply segregated, led him to participate in the creation of the Pan-African market, where the magazine Chimurenga came alive, initially as a short-lived editorial project. 
Ntone had started writing in Lagos, and he was involved in publishing activities for a few years, with his Pan-African sport journal. The first issue of the magazine Chimurenga took shape later, from the start, with no clear idea of creating a durable magazine. It was initially a single publication dealing with the issue of 'Music and Politics', based on a paper that Ntone Edjabe wrote about Fela Kuti, and on invitations extended to his broad network of colleagues and friends (Figure 4).

The success of this first issue led to a series of other publications, as Ntone Edjabe received propositions from different authors, and Chimurenga started to take up a new place in the field of publishing in Cape Town. Stacy Hardy, a core member of Chimurenga since 2008, explains her vision of the publishing and literary scene in Cape Town, and the empty space that Chimurenga was filling when she discovered it:

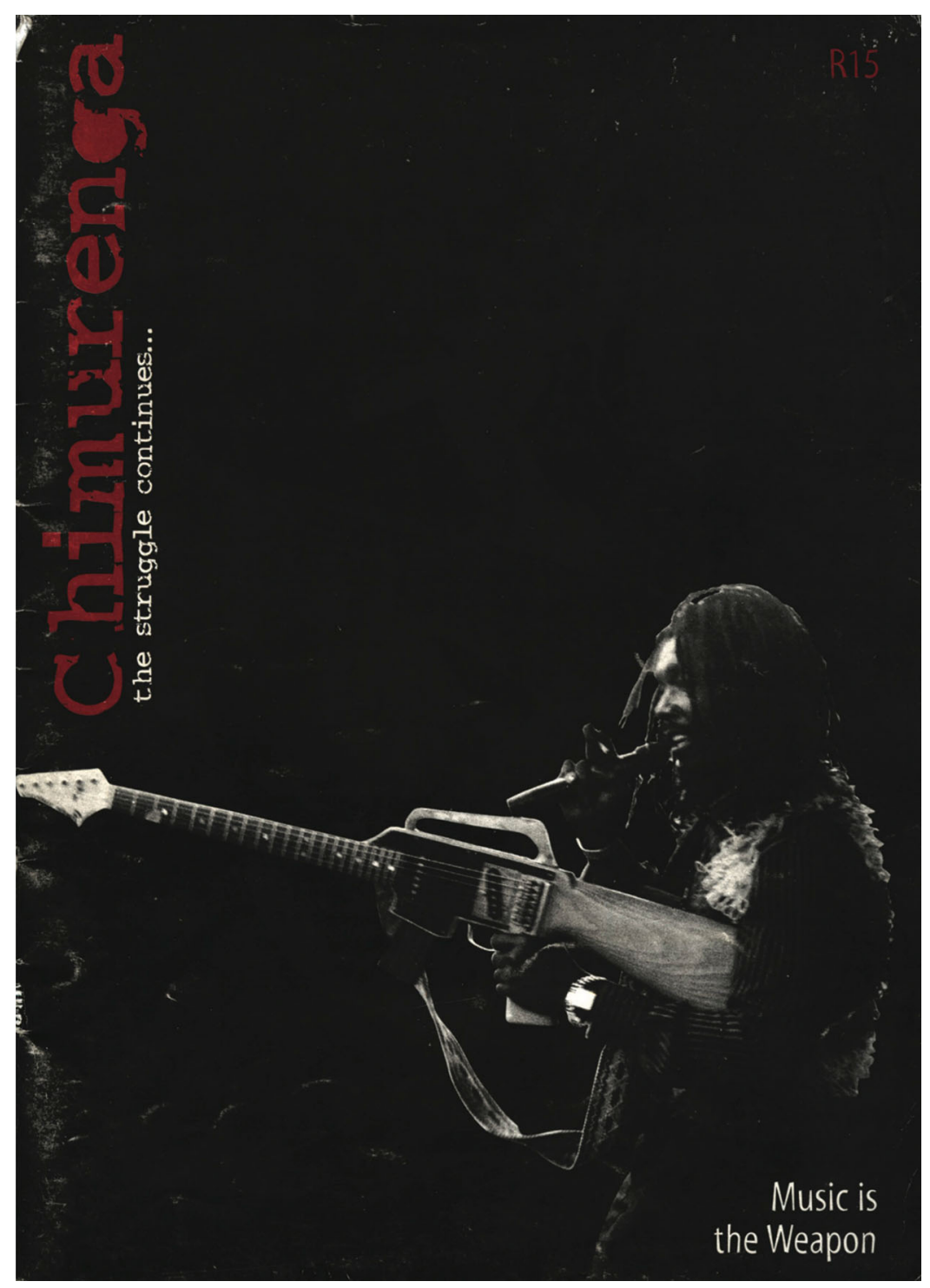

Figure 4. Cover page of the first issue of Chimurenga, 'Music is the weapon' (copyright $\odot$ Chimurenga). 
The literary scene was very white, conservative and middle class, and the kind of literature they were producing started to be increasingly driven by the market, and by the publishers who were all historically apartheid publishers, who remained in power and started opening little black imprints under the master power. The apartheid structures of publishing were kind of pushing a very one-dimensional view of a book (Interview with Stacy Hardy, August 2016, Cape Town).

With the heritage of a longer history of black consciousness and alternative media in South Africa (Tomaselli 2000), the consolidation of Chimurenga was answering directly to this context of the apartheid publishing world, that was materialising through the media's race discourses, conservative visions and dominant capitalist economic interests (Tomaselli 2000, 247-248; Steenveld 2004). The main project that led Chimurenga was based on the need to create and spread knowledge that was not anchored in Westernised and colonised systems of knowledge, focusing instead on what was conceived as 'indigenous' and 'popular' knowledge. Beyond nationalists' visions of a rainbow nation still embedded in racial categorisations (Wasserman and Jacobs 2003), Chimurenga's attempt was more turned towards the project of creating a postcolonial critical and heterogeneous glance on history and contemporary experiences of Africans, opening up the multi-faceted dimensions of what it means to be African in the world today.

The aim of these projects is not just to produce new knowledge, but rather to express the intensities of our world, to capture those forces and to take action. This has required a stretching of the boundaries, for unless we push form and content beyond what exists, then we merely reproduce the original form - the colonized form, if you will. It requires not only a new set of questions, but its own set of tools; new practices and methodologies that allow us to engage the lines of flight, of fragility, the precariousness, as well as joy, creativity and beauty that defines contemporary African life. ${ }^{12}$

In 2008, after several issues of his magazine, Chimurenga created the Chronic, a quarterly gazette, born from the idea that 'most knowledge produced on the continent remains heavily reliant on simplistic and rigid categories unable to capture the complexities that inflect so much of contemporary quotidian life here'. ${ }^{13}$ With that agenda, Chimurenga mobilised contributions by writers from different regions of Africa or beyond, academics, as well as non-academics, artists, musicians, painters, and comics makers. To challenge knowledge boundaries, the Chronic used original forms, mixing novella, essays, poetry, comics, sciencefiction, paintings and photographic creations, and addressed eclectic issues, ranging across topics such as the destruction of universities, to African cartographies and food.

While being related to its creator's visions, networks and projects, Chimurenga's work has since its inception been the result of deeply collaborative efforts. In addition to Ntone Edjabe and Stacy Hardy, the editorial team hires a Capetonian designer and DJ who is in charge of Chimurenga's animation and design (Graeme Arendse), a Zimbabwean journalist and writer (Bongani Kona), a German scholar (Moses März), and a range of other people who are involved in the editing of the journal. The publication involves famous writers from the South African literary and academic field, such as Achille Mbembe, Pumla Dineo Gqola and Sandile Dikeni, but also writers, scholars, musicians and artists from other African countries, the United States, and the rest of the world.

Through these transnational connections, Chimurenga challenges Cape Town's segregated and 'non-African' post-apartheid spatial organisation, unfolding knowledge and visions of a transnational pan-Africanism. In the course of their different activities, 
Chimurenga has collected a series of documents about Pan-Africanism, creating a fluid and moving archive, which crosses borders between genres, between the archive and the repertoire, and between text and performance.

\section{All roads lead to FESTAC? Building an archive of Pan-African festivals}

In 2008, the collective Chimurenga connected with the WikiAfrica literature project (a section of WikiAfrica ${ }^{14}$ that intends to bring more African literature to Wikipedia), with the idea of collecting and documenting the story of independent Pan-African paper periodicals. They created their Chimurenga Library, an online library ${ }^{15}$ that presents the genealogies of publications that have inspired Pan-African writing and thinking, but that remain largely unknown abroad, such as Souffles, Third Text and African Film. While following the history of African magazines and writers, such as Wole Soyinka, Ngugi Wa Thiong'o, Keorapetse Kgositsili, they have noted the core importance of some hubs and historical moments, where the routes of these writers crossed, such as festivals and congresses ${ }^{16}$ that took place on the continent and in the diaspora after independence. Ntone Edjabe knew about the existence of FESTAC when he lived in Lagos but was not conscious of the scale of the event, and it was at this time that he discovered the many routes that crossed at this historical moment. FESTAC was gathering and putting into a dialogue many of the musicians that Ntone Edjabe was fascinated by, and that he was playing during his DJ sessions: Fela Kuti and the counter FESTAC that he organised in Lagos in 1977 (Veal 2000), the Blue Notes South-African anti-apartheid jazz band, Miriam Makeba, or the Tout Puissant Orchestre Polyrythmo from Cotonou. He and his team progressively understood from that moment how the history of Pan-African festivals was encompassing all the issues, pathways, and people that Chimurenga was interested in (Interview with Ntone Edjabe; interview with Stacy Hardy; http://chimurengalibrary.co.za/).

From 2010, they started to pay more attention to these festivals, considering that it could help to understand present politics, culture, and geopolitics in Africa. ${ }^{17}$ They oriented their participation in foreign exhibitions, consciously following this intention of collecting and producing knowledge of this history. With funding from the Tate Museum, they explored the official archives and memories of FESTAC in Lagos in 2013. They scanned a part of the official archives collected by the Centre for Black and African Arts and Civilization (CBAAC), including a huge number of identity cards created for the participants of the festival, which gave shape to the individual routes of people whom Chimurenga is following, or maps of the town. Then from 2014 to 2016, the Chimurenga team presented exhibitions and programmes about FESTAC and Pan-African festivals in collaboration with international libraries and art festivals in four main places where they received funding and infrastructural support: San Francisco, London, New York, and Helsinki.

In each case, the exhibition elaborated by the Chimurenga collective drew on their own materials and items, as well as on local objects or people, to give shape to and to reconnect the different routes and memories of FESTAC. In their exhibition in New York for the Performa 15 (November 2015), they called for the participation of Marilyn Nance, and they used her photographs in the exhibition. One year before, in May 2014, the exhibition organised in the San Francisco Public Library had been a way to meet former members of the Black Panther Party and to explore their archives. ${ }^{18}$ Several people from the Bay area who had been to FESTAC 1977 participated in the round-table of discussions 
organised during the exhibition. In London, they collected a large number of interviews recorded by the Transcription Centre, a radio programme created for and about Africa in London in the 1960s (Moore 2002) which, from 1962 to 1970, broadcasted many interviews with African writers and artists. ${ }^{19}$ Even if not always directly related to the FESTAC itself, these materials are relevant for Chimurenga as part of a story of the imagination of African identities and liberation struggles through exile.

As we observe through these examples, the production of this archive is partly contingent, and dependent on the circulations and encounters of the Chimurenga team; it mixes official institutional archives with personal collections, such as Marilyn Nance's gallery of photographs, or Ntone Edjabe's own music collections. Thus, the collection developed corresponds not to a formal and stable archive, but to an informal and unstable collection of materials that Chimurenga uses in its activities. It is always re-enlivened in their performances, and never enclosed in a locked repository.

Furthermore, the collection of materials gathered by Chimurenga is not the product of an intentional will to create a complete archive, nor of a methodological practice of research. It forms part of their usual practice of archiving and conservation of the documents that they used, whether it be the thousands of discs of the Pan-African Space Station, the books and magazines in the Chimurenga Library, the music performances filmed or the interviews made with artists, that they conserved and shared on their radio and website. In that sense, we can relate their practice to the work of contemporary artists (Foster 2004; Osthoff 2009), who change the archive ontology and challenge its former stability and meaning. As explained by Hal Foster about contemporary artists: 'The work in question is archival since it not only draws on informal archives but produces them as well, and does so in a way that underscores the nature of all archival materials as found yet constructed, factual yet fictive, public yet private' (Foster 2004). In other words, and as described by Tsitsi Jaji, Chimurenga keeps 'scrambling the grand narratives of history, by archiving what is yet to come' (Jaji 2014, 229). As is described in the final part, Chimurenga's work also contributes to challenging the idea of the archive, transformed through their practice into a 'dynamic and generative medium' (Osthoff 2009).

\section{A moving archive of FESTAC: diffusing a Pan-African memory}

Rather than a complete archive, the archive is a disorganised store of documents that have been accumulated through the journeys of Chimurenga. They transform, cut, and select this collection according to their interests in these topics, with no sacralisation of the idea of a complete archive. The cohesion of this archive relies on a storage and organisation that Chimurenga has developed for the aim of their exhibitions and performances, and that was still in process when I started working with them.

I went to Cape Town in July 2016 for six months of fieldwork research with Chimurenga, as part of a postdoctoral project about the memory of Pan-Africanism in South Africa. When I arrived in Cape Town and first met with Chimurenga members, I proposed that I was to be involved in their activities as a counterpart of my research on their material 'archive'. Ntone Edjabe's first reaction was that their collection could hardly be described by the term 'archive', as it corresponded more to an unorganised, multiform and fragmented series of heterogenous documents (informal conversation with Ntone Edjabe, July 2016, Cape Town). We agreed that I would participate in the indexing, organisation, and 
classification of their materials about FESTAC and other Pan-African festivals. I spent almost six months organising, listing, and tagging all their materials, following their topics and system of classification, in order to create a website and a book about PanAfrican festivals (that will be available in 2019).

My main entry into Chimurenga's collection was a spreadsheet (in the form of an Excel document), that lists most of the documents (digital and material) that Chimurenga has collected. The spreadsheet is divided into several pages, for each type of document: album covers, audio, images, posters, newspapers, pamphlets/newsletters, research, video, publications, and quotes. All entries of the broadsheet relate to documents stored on Chimurenga's hard drives (such as ID cards, posters, videos), or to some material documents that they keep in their offices, such as copies of FESTAC books, or vinyl albums that are part of the Pan-African Space Station collection.

One of my main surprises when I first started to work on this document was that there was no distinction made between sources or raw materials, and the documents created by Chimurenga. For example, the video section included films made by the team, archive documents collected in CBAAC, links to websites where the interviews filmed by the Panafest team are stocked, but also new video edits created by Chimurenga and their collaborators as part of their exhibitions, such as the video '!ne(gr)o', edited by Neo Muyanga - a musician and co-creator with Ntone Edjabe of the Pan-African Space Station. Nevertheless, materials were organised following a specific order, which corresponds to Chimurenga's reading and analysis of these events. Indeed all the materials collected, sampled, and transformed by Chimurenga (posters, books, newspaper, discs, songs, interviews, recordings) are identified and categorised in the Excel spreadsheet in terms of 'tags' (a list of thematic titles), that allow them to circulate in the history of Pan-African festivals and to use these festivals and people that were involved as broader anchoring points in the African history: 'Black communities and performance of Pan-Africanism', 'Counter-Festac', 'Oil power and culture', 'Staging national culture'.

One particularly powerful example is the collection of quotes, books, music and album covers of Fela Kuti which are used to describe the existence of a 'counter-FESTAC', and of alternative conceptions of Pan-Africanism than the state-sponsored vision promoted by the Nigerian military state. Indeed, Fela strongly criticised the authoritarian organisation of FESTAC, even proposing an alternative programme to the event: he organised a counter-FESTAC in his Shrine during FESTAC, which many musicians and participants in the official festival attended. In several documents collected by Chimurenga, there is evidence of having encountered another image of Africa in this place, leading FESTAC participants to new inspirations in their music or their political activity, as evidenced by the case of Thabo Mbeki (Gevisser 2007).

Using these archives, people, documents, and themes, Chimurenga conceives of its exhibitions as a 'low tech time-traveling machine ${ }^{20}$ to the past and for the production of memory. In their San Francisco exhibition, this time-travel machine was created through several channels and instruments: the library was used to guide the visitor on a journey through the history of Pan-African festivals, guided by both items and thematic organisation. Following quotes of books and tapes pasted on the floor, the visitor was guided to look at books, videos, pictures, flags, or objects, based on the different themes Chimurenga had identified and used to organise its materials (Figure 5). 


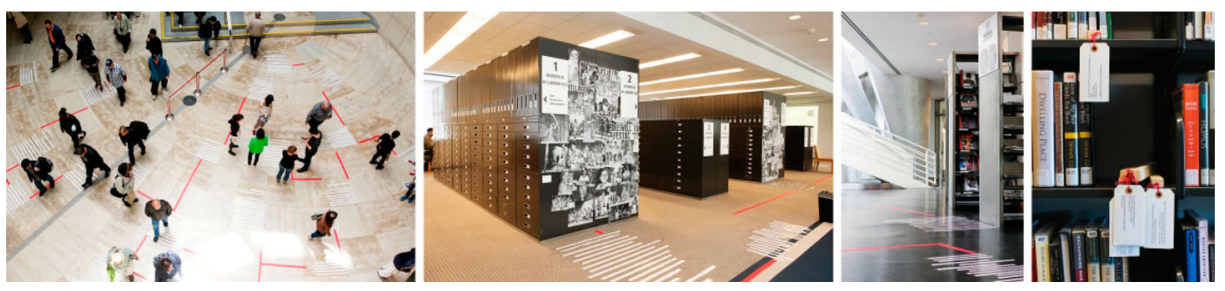

Figure 5. Chimurenga's exhibition at the San Francisco Public Library, 2014.

In this exhibition, as in all the work of Chimurenga, in order to travel through the history of Pan-African festivals, the operation of cutting, selecting, and sampling small extracts or records of broader collections has a core importance. The work of Chimurenga for travelling through the history of Pan-African festivals consists mainly of the operation of cutting, selecting, and sampling small extracts or records from broader collections, that they mix with others in order to create new pieces, performances and arenas of discussion about Pan-Africanism. Sampling from archives is more broadly the basis of archivists' and historians' work (Kepley 1984), when they need to cull the most significant files or documents from a large record series. Here, this sampling and remixing practice is based on the thousands of books that constitute the Chimurenga library in order to create quotes, on their discs, pictures and videos in order to create new short films, and it does not have the aim merely to appraise the relevance of the collection, but also to create new pieces based on the samples created. For example, quotes represent for them documents per se, with their own section in the spreadsheet document, which are used as the basis for exhibitions.

Chimurenga performs and shares this archive of Pan-Africanism in the global sphere, through exhibitions in institutions such as the San Francisco Public Library, but they rarely organise such events in Cape Town, where they receive fewer invitations and less funding. During one of the meetings that I attended during my research, Ntone explained to the team that after having travelled and performed in many places, they needed now to reach new targets, and to address their local context more. He noticed that they are 'isolated from what's happening in the city and the country', and that they need to reconnect their practices with 'what's happening or not happening in the streets' of Cape Town, through interventions in schools, and through the purchase of a newly opened place in town where they would organise more events.

Even if its local influence is smaller than its global connections, Chimurenga's collection of documents and the memory of Pan-Africanism that they create is also nourished by the local context in South Africa where they are settled. On the one hand, many of their archives about Pan-African festivals are related to South African figures, whether it be artists such as Miriam Makeba, Hugh Masekela, Lefifi Tladi, or political figures such as Thabo Mbeki. Their research about Pan-African festivals intertwines and melts into a broader exploration of South African history of liberation struggles. Furthermore, even if they are not always focused directly on FESTAC or Pan-African festivals, many of the events that they organise contribute to create a memory of Pan-Africanism and past struggles for African freedom in Cape Town. As noted by Tsitsi Jaji, Chimurenga's Pan African Space Station inaugural event was launched in 2009 at the occasion of the thirty-first anniversary of Steve Biko's death, celebrating the memory of this black consciousness icon. Through his internet interventions or pop-ups in varied places of Cape 
Town, they 'cross economic and (still) racial boundaries of Cape Town's neighbourhoods' (Jaji 2014, 235), transcending territorial borders of the apartheid.

On 30 November 2016, Chimurenga organised in their Pan-African market office an event billed as a special Mbizo tribute, to honour the anniversary of Johnny Dyani, a famous South African jazz double bassist. ${ }^{21}$ Born in East London in 1945, Johnny Dyani was part of the Blue Notes, a multiracial and anti-apartheid jazz band formed in Cape Town in the 1960s. He left South Africa with his band in 1964, fleeing the apartheid regime and the repression that was imposed. The Blue Notes toured all around the world in the 1970s, and they participated in FESTAC in 1977. Several documents of Chimurenga's archive are related to the Blue Notes and to Johnny Dyani, including interviews in which he and the members of his band recount their experience of FESTAC, or play pieces of music. Johnny Dyani represents one of the many routes that lead to FESTAC, which allows Chimurenga to remember a time of struggle and exile for South Africa.

The Mbizo tribute event was mainly conceived as a tribute to this jazz musician and composer, through a 24-hour live broadcast of music written or performed by the artist. The event was also an occasion to gather a musical and artistic scene which shares the memory of exile, travels, and political struggles of the 1970s, connecting older musicians, sounds, and memories about the history of Pan-Africanism, and some members of the contemporary music scene in Cape Town. During these 24 hours, Chimurenga's office welcomed artists like Keorapetse Kgositsile, Lesego Rampolokeng, and Louis Moholo, the famous drummer of the Blue Notes with Johnny Dyani, who also participated in FESTAC in 1977. A few days before the event, Louis Moholo had given an interview to Chimurenga during which he had shared his memory of Johnny Dyani and of FESTAC, offering a testimony which would be added to Chimurenga's collection of materials.

Through this event, Chimurenga was thus creating new materials, by collecting interviews and testimonies added to their collection or shared on their website, and they were maintaining the liveliness of their archive, by performing music and interviews. It was also an opportunity to gather people who had collaborated with Johnny Dyani or had been inspired by his music, and implicitly a way to connect past and present routes of South African artists, and past and present struggles for Black consciousness. Through events such as the Mbizo tribute, Chimurenga posits itself in Cape Town as a crossroads of many routes and temporalities, connecting Cape Town to the world, connecting past and present African struggles.

\section{Conclusion: performing a transnational memory of Pan-Africanism in Cape Town}

This article has described how, since 2002, Chimurenga has assembled a broad collection of materials that they employ as an entry point to disseminate their conception of African history, culture, and politics. They use original or re-worked archives to produce memories and to address the present situation in Africa. These archives and memories coming from Lagos, Algiers, Dakar (and from all the travelling routes that these events connected), are created and disseminated through their exhibitions, where they encounter local memories of FESTAC to co-produce knowledge about this event and discuss how to imagine contemporary representations of Africa. Even if they are apparently struggling to exert an influence in Cape Town, through their publications, musicals performances, and pop-up 
events, their exhibitions and transnational network to which they contribute, Chimurenga constitutes a main actor in contemporary cultural Pan-Africanisms, in South Africa and abroad. While Chris Saunders has noted the small number of research interventions dealing with the history of Pan-Africanism and transnational liberation struggles in Cape Town (Saunders 2010), this hybrid project challenges frontiers between the academy and art to spread subversive memories and visions of Africa. Chimurenga has not yet created an official public archive, but their attempt contributes to recording oral memories and to documenting liberation struggles in Southern Africa (Isaacman, Lalu, and Nygren 2005; Saunders 2010; Sapire and Saunders 2012).

Using different domains and medias, navigating between art, academia and popular culture, and between past, present, and future, Chimurenga challenges normative conceptions of history and invents new systems of classification regarding knowledge, its production and dissemination. Through their multimodal platform and their evolving archive, they propose a virtual space which allows (South) Africa to imagine its global solidarities, including different times, different spaces and different worlds.

In Cape Town, it is possible to observe strong claims for Africanism, with often more radical conceptions of a racial Pan-Africanism (for example by intellectuals sharing an idea of cultural Pan-Africanism gathering only sub-Saharan Africa), ${ }_{i}^{22}$ some artistic projects are also organised around the memory of South African liberation struggles, such as the performance 1976 spirits curated by Mandla Mbothwe and presented in Artscape theatre in September $2016,{ }^{23}$ to excavate the memory of the events of 1976 . Through their archival impulse, Chimurenga tries to create a dialogue between these local memories of liberation struggles with broader Pan-African movements and understandings of Pan-Africanism. In this way, they encourage contemporary South Africa to imagine itself beyond spatial and conceptual categories built by apartheid. ${ }^{24}$

\section{Notes}

1. 'Across the board: Interdisciplinary Practices', Sponsored by Guaranty Trust Bank Plc., Organised by Tate Modern in collaboration with Chimurenga, Centre for Contemporary Art, Lagos and Terra Kulture.

2. Online: http://www.chimurenga.co.za/about-us (accessed April 2018).

3. https://panafricanspacestation.org.za/

4. http://chimurengachronic.co.za/

5. I warmly thank the Chimurenga team and Ntone Edjabe for their generosity and their kind support of my research.

6. For other reflections about art and the archive in South Africa, see also Brenton Maart (2013), which deals mainly with performance and art from colonial and archives of the apartheid, but that proposes interesting common visions on the role of archives history in the present (Maart 2013, 35).

7. Ebony, May 1977, '29 Days That Shook the Black World', p. 48.

8. This led to tensions within the organising committee, which was planned to be co-directed with Senegal, to Senghor's abdication of his position of co-patron, and to his refusal to attend the festival, because of the presence of North African Arab countries.

9. Connecting four main cultural events that took place on the continent after independence, they question how these platforms 'have played a pivotal role in the development of cultural and political movements in Africa from the 1950s to the present'. See their archive online: http://www.iiac.cnrs.fr/article477.html 
10. See Turok 2001; Lemanski 2004; Miraftab 2007. Charlotte Lemanski narrates that 'post-apartheid Cape Town continues to exhibit ruthless spatial polarization, dominated by the juxtaposition of centrally located affluent suburbs and economic centres alongside poverty-stricken and overcrowded settlements on the city edges' (Lemanski 2004, 103).

11. This brief biography of Ntone Edjabe is based on an interview that I conducted with him in August 2016.

12. For the presentation of Chimurenga by themselves, see their website: https:// chimurengachronic.co.za/store/

13. Chimurenga's description of the Chronic, http://chimurengachronic.co.za/about/

14. See online: https://en.wikipedia.org/wiki/Wikipedia:WikiAfrica

15. http://chimurengalibrary.co.za/

16. We can quote the Congress of Black Writers and Artists that took place in Paris in 1956 and Rome in 1959, and that represents ancestors of Pan-African festivals, like the Pan-African congresses organised at the beginning of the century.

17. See Borggreen and Gade 2013.

18. Indeed, the Black Panther Party participated in Panaf 1969 and even if they were not in FESTAC, their routes and actions for liberation struggles are anchored in the history of liberation struggles that Chimurenga unfolds.

19. The Transcription Centre was funded by the Congress for Cultural Freedom (CCF), an organism whose funding and goals actually came from the U.S. Central Intelligence Agency (Moore 2002). More information is available on the website of the University of Austin in Texas, where a part of the archive is recorded. https://norman.hrc.utexas.edu/fasearch/findingAid. cfm?eadid $=00447$

20. https://chimurengachronic.co.za/store/

21. See about this event: https://panafricanspacestation.org.za/category/passblog/passnews/ page/6/?wpmp_switcher=mobile

22. See Prah 2014.

23. https://www.iol.co.za/capetimes/arts-portal/excavate-restore-and-celebrate-1976-spirits2070113

24. As called by previous scholars (Hamilton et al. 2002; Isaacman, Lalu, and Nygren 2005).

\section{Disclosure statement}

No potential conflict of interest was reported by the author.

\section{Funding}

This work was supported by a postdoctoral grant from the Foundation Maison des Sciences de I'Homme and the French Institute of South Africa (Johannesburg).

\section{References}

Adi, Hakim. 2018. Pan-Africanism: A History. London, New York Oxford New Delhi Sydney: Bloomsbury Academic.

Apter, Andrew. 2005. The Pan-African Nation: Oil and the Spectacle of Culture in Nigeria. 1st ed. Chicago: University of Chicago Press.

Baumann, Stéfanie. 2009. "Archiver ce qui aurait pu avoir lieu. Walid Raad et les archives de l'Atlas Group." Conserveries Mémorielles 6: 2-21.

Bonacci, Giulia. 2010. Exodus, I'histoire du retour des Rastafariens en Ethiopie. Paris: L'Harmattan.

Borggreen, Gunhild, and Rune Gade, eds. 2013. Performing Archives/Archives of Performance. Copenhagen: Museum Tusculanum Press. 
Bosch Santana, Stephanie. 2016. "Exorcizing the Future: Afropolitanism's Spectral Origins." Journal of African Cultural Studies 28 (1): 120-126.

Boukari-Yabara, Amzat. 2014. Africa Unite! Une histoire du panafricanisme. Paris: La Découverte.

De Jong, Ferdinand, and Elisabeth Harney, eds. 2015. "Art from the Archive". African Arts 48 (2): 1-4.

Ekpo, Denis. 2008. "Festac 77 et le projet de modernité africaine : des méfaits d'un nationalisme culturel excessif." Africultures 73 (2): 26-34.

Falola, Toyin, and Kwame Essien. 2013. Pan-Africanism, and the Politics of African Citizenship and Identity. London: Routledge.

Ficquet, Éloi, and Lorraine Gallimardet. 2009. “On ne peut nier longtemps l'art nègre:. Enjeux du colloque et de l'exposition du Premier Festival mondial des arts nègres de Dakar en 1966." Gradhiva 10: $134-155$.

Foster, Hal. 2004. "An Archival Impulse." October 110: 3-22.

Gallimardet, Lorraine. 2010. "Libération de l'Afrique au festival Panaf' d'Alger." Afrique Contemporaine 235 (March): 70-71.

Gevisser, Mark. 2007. Thabo Mbeki: The Dream Deferred. Cape Town: Jonathan Ball Publishers.

Guedj, Pauline. 2012. Panafricanisme, religion akan et dynamiques identitaires aux Etats-Unis. Le chemin du Sankofa. Paris: L'Harmattan.

Hamilton, Carolyn, Verne Harris, Jane Taylor, et al., eds. 2002. Refiguring the Archive. Cape Town: David Philip.

Harris, Verne. 2002. "The Archival Sliver: Power, Memory, and Archives in South Africa." Archival Science 2: 63-86.

Isaacman, Allen, Premesh Lalu, and Thomas Nygren. 2005. “Digitization, History, and the Making of a Postcolonial Archive of Southern African Liberation Struggles: The Aluka Project." Africa Today 52 (2): 55-77.

Jaji, Tsitsi Ella. 2014. Africa in Stereo: Modernism, Music, and Pan-African Solidarity. Oxford: Oxford University Press.

Kepley, David R. 1984. "Sampling in Archives: A Review." American Archivist 47 (3): 237-242.

Le Lay, Maëline, Dominique Malaquais, and Nadine Siegert, (dir.) 2015 Archive (re)mix : vues d'Afrique. Rennes: Presses universitaires de Rennes.

Lemanski, Charlotte. 2004. "A new Apartheid? The Spatial Implications of Fear of Crime in Cape Town, South Africa." Environment \& Urbanization 16 (2): 101-112.

Maart, Brenton, ed. 2013. Imaginary Fact. Contemporary South African Art and the Archive. Grahamstown: National Arts Festival.

Malaquais, Dominique, and Vincent Cedric. 2016. "Panafest: a Festival Complex Revisited." In The First World Festival of Negro Arts, Dakar 1966: Contexts and Legacies, edited by David Murphy, 194-202. Liverpool: Liverpool University Press.

Mangcu, Xolela, ed. 2011. Becoming Worthy Ancestors: Archive, Public Deliberation and Identity in South Africa. Johannesburg: Wits University Press.

Mbembe, Achille. 2004. "Aesthetics of Superfluity." Public Culture 16 (3):373-406.

Miraftab, Faranak F. 2007. "Governing Post-Apartheid Spatiality: Implementing City Improvement Districts in Cape Town." Antipode: Radical Journal of Geography 39 (4): 602-626.

Moore, Gerald. 2002. "The Transcription Centre in the Sixties: Navigating in Narrow Seas." Research in African Literatures 33 (3): 167-181.

Murphy, David. 2016a. "Archiving the First World Festival of Negro Arts (Dakar 1966): Recuperation, Nostalgia and Utopianism." World Art 6 (1): 125-146. https://doi.org/10.1080/21500894.2016. 1165730.

Murphy, David, ed. 2016b. The First World Festival of Negro Arts, Dakar 1966: Contexts and Legacies. Liverpool: Liverpool University Press.

Nance, Marilyn and Fanny Robles (Interview with Marilyn). 2017. "FESTAC 77 à Lagos : la mémoire photographique de Marilyn Nance". Africultures (blog). 30 janvier 2017. http://africultures.com/ festac-77-a-lagos-la-memoire-photographique-de-marilyn-nance-13953/.

Nora, Pierre, ed. 1984. Les Lieux de mémoire. T.1 La République. Paris: Gallimard.

Osthoff, Simone, ed. 2009. Performing the Archive: The Transformation of the Archive in Contemporary Art from Repository of Documents to Art Medium. New York: Atropos Press. 
Prah, Kwesi Kwaa. (compiled by). 2014. Africanism or continentalism: mobilizing global Africans for Renaissance and Unity, Selected Documents Of The 8th Pan-African Congress. Rondebosch: Centre For Advanced Studies Of African Society Casas, CASAS Book Series $n^{\circ} 110$.

Sapire, Hilary, and Chris Saunders, eds. 2012. Southern African Liberation Struggles: New Local, Regional and Global Perspectives. Cape Town, South Africa: University of Cape Town Press.

Saunders, Chris, ed. 2010. Documenting Liberation Struggles in Southern Africa: Select Papers from the Nordic Africa Documentation Project Workshop 26-27 November 2009, Pretoria, South Africa.", The Nordic Africa Institute. On Line: http://www.diva-portal.org/smash/record.jsf?pid=diva2:344963.

Shepperson, George. 1962. "'Pan-Africanism' and 'Pan-Africanism': Some Historical Notes." Phyllon XXIII (4): 346-358.

Steenveld, Lynette. 2004. "Transforming the Media: A Cultural Approach." Critical Arts 18 (1): 92-115. Tomaselli, K. G. 2000. "South African media, 1994-7: Globalising via Political Economy." In DeWesternizing Media Studies, edited by J. Curran and M. J. Park, 247-259. London: Routledge.

Turok, Ivan. 2001. "Persistent Polarisation Post-Apartheid? Progress towards Urban Integration in Cape Town." Urban Studies 38 (13): 2349-2377.

Veal, Michael E. 2000. Fela : The Life \& Times of an African Musical Icon. Philadelphie: Temple University Press.

Wasserman, Herman, and Sean Jacobs. 2003. Shifting Selves: Post-Apartheid Essays on Mass Media, Culture, and Identity. Cape Town: Kwela Books. 